Tomasz Peciakowski

Instytut Socjologii

Katolicki Uniwersytet Lubelski Jana Pawła II

\title{
POLOWANIE NA INTELEKTUALISTÓW* ROLA I MIEJSCE ELITY INTELIGENCJI W ŻYCIU PUBLICZNYM
}

\section{Wprowadzenie}

W polskich naukach społecznych wiele miejsca poświęca się problemom polskiej inteligencji i powstawaniu współczesnych jej odpowiedników (jak professionals, specjaliści) - to oni bowiem rozpowszechniają idee, które mają znaczący, a często nawet decydujący wpływ na kierunek zmian społecznych. Pomimo bogatej literatury na temat przekształceń i zróżnicowania zawodowego inteligencji, czego odzwierciedleniem jest jej podział na odrębne segmenty (Domański 2008), brakuje opracowań traktujących o - będącej jednym z tych segmentów - elicie inteligencji, czyli intelektualistach. To oni przecież te rozpowszechniane przez inteligencję idee tworzą i modulują, dodając im społecznej atrakcyjności. I mimo że wiele wiemy o ich życiorysach i ideach, które promują, mimo iż poświęca się im setki reportaży, pisze liczne biografie, publikuje ich korespondencje oraz wywiady-rzeki, a co najważniejsze, oni sami poprzez liczne

\footnotetext{
* Tym zwrotem zatytułowano opublikowane w 1992 r. w czasopiśmie „Arka” (nr 37-38) wyniki rozesłanej do „wybitnych przedstawicieli życia umysłowego” ankiety, w której m.in. pytano: „Czy uważa się Pan (Pani) za intelektualistę, inteligenta?" Choć wśród odpowiadających były takie osoby, jak Jan Józef Szczepański, Gustaw Herling-Grudziński, Tomasz Strzembosz, Ludwik Haas, Krystyna Kersten, Piotr Wierzbicki czy Bronisław Łagowski - na przepytanych 14 osób - 12 przyznało, że określenie ,inteligent” (mniej lub bardziej) do nich pasuje, podczas gdy aż 13 z nich uznało, że na pewno nie są intelektualistami. Wbrew pozorom nie był to przejaw skromności wybitnych twórców, ale fatalnych skojarzeń, które przylgnęły do pojęcia ,intelektualisty” w Polsce (zob. Fik 1997: 9-12).
} 
apele, listy i manifesty ukazują się nam w całym swoim jestestwie, wciąż brakuje badań na ich temat. I o ile nauki społeczne na całym świecie, debatują i spierają się o to, jak definiować intelektualistów, jak ich umiejscowić w strukturze społecznej, i w końcu, jak ich badać, o tyle polska socjologia na ten temat właściwie milczy, całą swą uwagę poświęcając studiom nad inteligencją, gdzie problem intelektualistów zazwyczaj jest omijany albo traktowany bardzo powierzchownie. Tymczasem już Jan Szczepański wskazał (1960), że rola tej specyficznej, elitarnej grupy inteligentów, jest nie do przecenienia.

Niniejszy artykuł ma być głosem przypominającym polskim badaczom, że wśród wielu wątków, jakie podejmował Szczepański w swoich pracach, a których nie udało mu się rozwinąć, jeden z nich szczególnie jest warty przypomnienia wątek intelektualistów. Dlatego celem niniejszego artykułu będzie ukazanie sensu traktowania intelektualistów jako odrębnej kategorii społecznej i zachęcenie do rozpoczęcia na gruncie polskiej socjologii starań ich rozpoznania i zbadania ${ }^{1}$. Sukces takiego przedsięwzięcia może wyposażyć naukę w ważne źródło zdobywania wiedzy o narodowych sporach i polskim życiu publicznym. Zanim jednak łowiecki róg da sygnał do polowania, warto zastanowić się, kto dokładnie będzie zwierzyną łowną i jak ją rozpoznać w tej społecznej (ale i słownej) gęstwinie.

\section{Geneza w trzech wymiarach}

Geneza intelektualistów sięga głęboko w historię i społeczne dzieje. Ich praprzodków można szukać już u platońskich sofistów i średniowiecznych scholastyków, choć panuje raczej zgodność, iż jest to postać charakterystyczna przede wszystkim dla rzeczywistości demokratycznej, gdzie autonomia umysłu i krytyczne spojrzenie może realizować się w pełni. Ich geneza może być jednak rozpatrywana w trzech wymiarach - jako słowo (pojęcie), postać (typ osobowy) oraz jako warstwa społeczna (charakterystyczna ze względu na cechy społeczne grupa osób). Warto pokrótce scharakteryzować każdy z nich.

Rozpowszechnione jest raczej przekonanie, że pojęcie „intelektualisty” pojawiło się po raz pierwszy we Francji (fr. - intellectuel), tam bowiem zjawisko to miało przyjąć swoją modelową formę (zob. Bourdieu 2007, Szacki 1991, Żarnowski 1998) - rzeczywiście, w sposób powszechny weszło do literatury światowej od tzw. sprawy Dreyfusa i francuskiego Manifeste des intellectuels! z 1898 roku. J. Szczepański (1991) wskazuje jednak, że samo słowo pojawiło się

${ }^{1}$ Autor niniejszego artykułu jest właśnie w trakcie realizacji badań na polskimi intelektualistami. 
po raz pierwszy w języku angielskim (w 1. mn. jako intellectualists), a nie francuskim, i to o wiele lat wcześniej, bo już w 1605 r. u Francisa Bacona (1915: 33), który w pracy The Advancement of Learning określił tak myślicieli, którzy oddają się spekulacjom rozumowym kosztem nauk przyrodniczych i empirii, stanowiąc zagrożenie dla postępu nauki. Oczywiście nie zmienia to faktu, że do popularności pojęcia przyczynił się przede wszystkim wspominany Manifest intelektualistów, opublikowany 14 I 1898 r. na łamach „L’Aurore” przez Georgesa Clemenceau, który nazwał tym mianem obrońców kapitana Dreyfusa.

W języku polskim pojęcie ,intelektualista” - najprawdopodobniej po raz pierwszy - odnajdujemy w 1859 r. w Dykcjonarzu, zawierającym ,,wyrazy i wyrażenia z obcych języków polskiemu przyswojone", autorstwa Michała Amszejewicza (1859: 213). Pojęcie to pojawia się z podwójnym ,l” (,intellektualista”) i oznacza zwolennika rozumu, który dowodzi, że ,zmysły pozór tylko rzeczy nam przedstawiają, rozum zaś samą istotę rzeczy, czyli prawdę nam odkrywa”. Słowo „,intelektualista” przez wiele lat było używane w Polsce głównie w języku potocznym w stosunku do osób (najczęściej pracowników umysłowych), odznaczających się wyższą kulturą umysłową i przewagą intelektu nad temperamentem. Było to określenie o synonimicznym znaczeniu, jak mędrzec, humanista czy człowiek wykształcony, oczytany - pojęcie raczej opisowe niż odnoszące się do konkretnej kategorii osób (etos zaangażowania w życie społeczne utożsamiany był zaś z inteligencją). Moda na intelektualistów, która zapanowała na Zachodzie (specyficznym wyjątkiem jest tu Wielka Brytania - zob. Micińska 2000) w pierwszej połowie XX w. dotarła nad Wisłę z opóźnieniem. O intelektualistach zaczęto głośno mówić w Polsce dopiero w powstającym na wojennych zgliszczach ,nowym, lepszym świecie”. Dla zaangażowanych w jego budowę twórców kultury przewidziano tam miejsce szczególne - zapowiadał to już Światowy Kongres Intelektualistów, odbywający się w 1948 r. we Wrocławiu, jeden $\mathrm{z}$ elementów rozkręcającej się machiny propagandowej nowonarodzonej władzy. Zawłaszczony $\mathrm{w}$ ten sposób termin wpadł na długie lata w sidła pejoratywnych skojarzeń (,heglowskie ukąszenie”, „hańba domowa”, ,zniewolony umysł”), z których po dziś dzień nie może się w pełni wyswobodzić.

W literaturze przedmiotu można zauważyć wyjątkową zgodność co do twierdzenia, że zjawisko, jakim jest powstanie intelektualistów, daje się zauważyć, zanim jeszcze doszło do jego konceptualizacji. Pytanie podstawowe dotyczy jedynie tego, jak głęboko powinniśmy się cofnąć, jak daleko w dziejach szukać początków tego fenomenalnego zjawiska. Kto był pierwszy: Zola, Rousseau, Aretino, a może Platon lub Sokrates? Gdzie wyłonilibyśmy pierwszych przodków intelektualistów - u starożytnych sofistów, średniowiecznych scholastyków, humanistów i ludzi renesansu, oświeconych encyklopedystów czy dopiero wśród XIX-wiecznych klerków? 
Osoby o wybitnych umysłach, trudniące się pracą twórczą i kreowaniem idei istniały już od wieków. Dlatego wielu badaczy jest zdania, że szukając genezy intelektualistów, należałoby właściwie zacząć od starożytnej Grecji (Schumpeter 1995; Fuller 2005). Sofiści i retorzy z V i IV w. p.n.e., mimo iż sami by zapewne takie porównanie oprotestowali, pasowaliby do tej roli doskonale. Jako filozofowie i płatni nauczyciele kształcili kadry ówczesnych demokratycznych polis, stanowiąc dość niezależną grupę twórców filozoficznych dzieł i refleksji. Jak słusznie zauważa Jan Szczepański (1991), być może do tego opisu pasowaliby nawet egipscy kapłani-uczeni, zgodnie z poglądem Herberta Spencera, który wywodził kategorię zawodową intelektualistów z pierwotnych funkcji szamana, a później kapłana.

W średniowieczu również odnaleźć można intelektualistów na miarę tamtych czasów. Wyraźnie jednak widać, że rzeczywistość demokratyczna czy republikańska, charakterystyczna dla cywilizacji helleńskiej czy łacińskiej jeszcze przed Chrystusem, sprzyjała autonomii myślenia i postawie krytycznej. Tymczasem cesarskie i królewskie czasy średniowiecza strzeżone nie tylko mieczem, ale i religijnymi dogmatami, tworzyły naturalną barierę dla ludzi intelektu, którzy byliby zainteresowani skierowaniem słów do ludu i poruszeniem kulturowych fundamentów. Możliwości takiego działania były niewielkie, a konsekwencje czynu, który nie spodobałby się władcy czy papieżowi, często tragiczne. Rola twórcy kultury tamtych czasów jawi się więc dość precyzyjnie - artysta miał malować, a uczony nauczać innych. Choć pracami umysłowymi zajmowali się wówczas najczęściej duchowni i urzędnicy państwowi, a ich intelektualna działalność była jedną z wielu aktywności, które podejmowali (jak i funkcji, które sprawowali), to właśnie w wiekach średnich zaistniały pierwsze uniwersytety, kształcące ludzi wybitnie wykształconych. Jak pisze J. Szczepański (1991), średniowieczne uniwersytety stały się instytucjami kształcącymi zawodowych twórców, zajmujących się filozofią, teologią, logiką czy dialektyką, prawdziwych „ludzi idei”. Wydaje się, że narodziny tych średniowiecznych twórców i myślicieli zbudowały fundament dla uformowania się późniejszych intelektualistów jako grupy.

Jednak to w humaniście - o czym wspomina J. Schumpeter (1995) - dostrzegać należy początków rodzącej się pomału autonomii przyszłego intelektualisty. Jako że łączący kilka profesji na raz humanista i tak zajmował się głównie językiem (słowem), szybko więc wszedł w takie dziedziny, jak kwestie obyczajowe, polityka, religia czy filozofia. Początkowo postawa krytyczna była umiarkowana (ze względu na królewskie, książęce i zakonne cugle), bo i widmo płonącego na stosie heretyka wciąż było zbyt realne - podobnie jak zaszczyty i wygody 
w przypadku bardziej pokornego umysłu. Aczkolwiek to humaniści mieli być pierwszymi twórcami słowa czy też sztuki, mającymi zarówno tak szeroką publiczność (coraz powszechniejszy stawał się druk, a wskaźnik analfabetyzmu zaczął wyraźnie spadać), jak i coraz większe możliwości kształtowania swojej postawy krytycznej, co stopniowo zmieniał nowo powstający system ekonomiczny.

Jeżeli intelektualiści średniowiecza zrodzili się w klasztorach, to właśnie dopiero kapitalizm obdarzył ich wolnością i uzbroił w prasę drukarską. Powolna ewolucja świeckich intelektualistów była jedynie pewnym aspektem tego procesu; zbieżne w czasie pojawienie się bowiem humanizmu i początków kapitalizmu jest wielce uderzające (Schumpeter 1995: 182).

I tak, choć kształtowanie się tej charakterystycznej postawy intelektualisty i stosunku do tego co polityczne wiąże się z wiekami wcześniejszymi, to jednak typ osobowy intelektualisty można dostrzec najpełniej w czasie Oświecenia w środowisku encyklopedystów i les philosophes, o których szeroko pisał Z. Bauman (1998). Choć dzieło burzenia ołtarzy i wprowadzania na tron rozsądku rozpoczął już Voltaire, to jednak za swoisty „,archetyp” nowożytnego intelektualisty - idąc za Paulem Johnsonem (1988) - można uznać Jana-Jakuba Rousseau, którego zasięg wpływu był „dramatycznie szeroki” i który po raz pierwszy w dziejach łączył w sobie wszystkie cechy intelektualisty-prometejczyka: „domaganie się prawa do odrzucenia w całości istniejącego porządku, ufność w swe zdolności przebudowywania go od podstaw zgodnie z zasadami przez siebie obmyślonymi; wiarę, że można to osiągnąc drogą rozwoju politycznego; wreszcie nie mniej istotną cechę - uznanie roli instynktu, intuicji i impulsu w postępowaniu człowieka" (ibidem: 10).

Można rzec, iż Voltaire i Montesquieu (najwięksi tamtych czasów) swymi rozprawami chcieli uczynić monarchię strawną dla filozofów i co bardziej oświeconych obywateli; byli to ostrożni reformatorzy, pełni śmiałości królewscy doradcy, atakujący religię i Kościół katolicki, próbujący monarchię ułagodzić na wzór angielski. J. J. Rousseau nie był królewskim szambelanem - u niego tron miał upaść, ponieważ fundamenty społeczeństwa nie znajdują się w królewskich pałacach, ale $\mathrm{w}$ równości drobnych właścicieli, to fundamenty, które nie akceptują przywilejów i półśrodków. O ile więc Voltaire czy Montesquieu toczyli swe potyczki na przedpolach, to Rousseau wytoczył ciężkie działa - po nich francuski Ancien Regime już się nie podniósł.

Gdy idzie jednak o intelektualistów - rozumianych jako warstwa czy klasa, połączonych więziami, wspólnotą celów, swoistą misją - tych, należy szukać właśnie pod koniec XIX w. we Francji, kiedy to nastąpiła niesamowita ekspansja twórców kultury. Między 1872 a 1901 r. liczba „ludzi pióra”, pisarzy i dziennikarzy wzrosła dwukrotnie, podobnie jak liczba uniwersyteckich wykładowców między 
1881 a początkiem wieku następnego (Drake 2005). To dlatego echa francuskiego fin de siècle i już zapowiadanej w tej pracy afery Dreyfusa, która zapoczątkowała pozytywne skojarzenia z pojęciem ,intelektualisty” i obudziła niemal mesjanistyczne poczucie wspólnoty u konkretnej grupy osób, trudniących się działalnością twórczą, były tak słyszalne. Larum podnosiło bowiem coraz więcej gardeł. Po jednej ze stron sporu - gdzie też swoją przystań znaleźli intelektualiści - narodził się wówczas swoisty bunt wobec ówczesnego państwowego systemu, zniewalającego jednostkę. Ktoś w końcu musi stanąć po stronie uciskanych - apelowano.

Emile Zola nie pasjonował się specjalnie polityką, wręcz dystansował się od niej. Jednak w szczytowym momencie kariery pisarskiej to „historia wplątała go w politykę" (Madajczyk 1999: 32). Stało się to właśnie za sprawą obrony Alfreda Dreyfusa, o uniewinnienie którego walczył Georges Clemenceau, polityk dotychczas przegrany, a wówczas próbujący swoich sił jako dziennikarz w „L'Aurore littéraire, artistique, socjale". Kiedy tylko okazało się, jak mało przekonujące są dowody winy francuskiego oficera, 13 I $1898 \mathrm{r}$. Zola napisał do prezydenta republiki sławny list, któremu Clemenceau (publikując w swoim piśmie) dał bardzo prowokujący tytuł: J'accuse (Oskarżam). Pisarz postawił w nim zarzut pogwałcenia zasad prawa i obywatelskich cnót. Przy czym nie chodziło tu jedynie o błąd sędziowskiego werdyktu i o naprawę tej sądowej pomyłki, ale przede wszystkim o fakt nikczemnego uderzenia $w$ fundamentalne wartości sprawiedliwość, wolność i prawdę. Można rzec, iż była to kontynuacja postawy „ojca intelektualistów”, Voltaire'a, który zaangażował się w sprawę mordu sądowego Jeana Calasa (zrehabilitowanego w 1765 r.). Chodziło więc o przekonanie, że pogwałcenie praw jednego człowieka oznacza pogwałcenie praw wszystkich obywateli - jak zwykł mawiać Clemenceau (Madajczyk 1999: 33). Sprawa Dreyfusa nie była więc czymś nowym, gdy idzie o polityczną postawę intelektualisty, przełomem zaś było zachowanie całej grupy - intelektualiści zajęli wówczas pozycję polityczną en masse, tłumnie.

Dzień później bowiem obrońcy tego niesłusznie - jak w końcu udowodniono - skazanego za szpiegostwo oficera wystąpili publicznie, pisząc manifest popierający list Zoli. Pod całością apelu żądającego zachowania gwarancji prawnych dla zwykłych obywateli podpisało się ponad 100 osób - naukowcy, pisarze i artyści, a wśród nich Marcel Proust, Guillaume Apollinaire, Anatole France, Charles Péguy, Lucien Herr, Charles Andler, a także Claude Monet czy aktorka Sarah Bernardt. Redagujący gazetę Clemenceau, opublikował nazwiska sygnatariuszy pod nazwą Manifeste des intellectuels (Manifest intelektualistów). Później, jeszcze przez niemalże dwie dekady publikowano listy, pod którymi znalazło się w sumie ponad 3000 podpisów, głównie profesorów, pisarzy, poetów, publicystów i dziennikarzy, ale także artystów - malarzy, muzyków czy aktorów. 
Dlatego też historycy francuscy (głównie Ory i Sirinelli 2002) ze sprawą Dreyfusa wiążą samookreślenie się grupy intelektualistów we Francji - podobnie zresztą jak Julien Benda (1900, 1928) czy Pierre Bourdieu (2007), ale także wielu innych autorów, którzy w tym wydarzeniu widzą w ogóle narodziny pewnej świadomości intelektualistów jako grupy, co miało przełożenie także na sytuację twórców kultury w innych państwach. Mimo, iż nazwani zostali wówczas klasą (w końcu królował aparat pojęciowy Marksa), nie była to grupa oparta na powiązaniach, mających znaczenie dla środków produkcji (w żaden opisany przez Marksa sposób), a raczej na braku, niedostatku tego powiązania. Jak twierdzą Kurzman i Owens (2002: 65), intelektualiści dostrzegali swoje interesy i potrzeby mniej więcej tam, gdzie leżały też interesy i zapotrzebowania społeczeństwa jako całości. Taka perspektywa była możliwa dzięki temu, że łączył ich komfort bycia zdystansowanym do wszechogarniającej walki o zajęcie ważnych pozycji w strukturze ekonomicznej. Jednocześnie - jak zauważa Schumpeter (1995) - głównym napędem powstającego blasku autorytetu intelektualistów był system kapitalistyczny i demokratyzacja (z jednej strony więc otwarty dostęp do bogactwa i prestiżu dla klasy burżuazyjnej, z drugiej zaś większa swoboda w sferze publicznej i rosnące znaczenie ,,anonimowej” opinii publicznej), co oznacza, że nawet jeśli intelektualista stał z boku kapitalistycznej maszynerii, to jego byt był silnie naznaczony mentalnością kapitalizmu, której uosobieniem była przecież burżuazja, główna publiczność intelektualisty.

\section{Intelektualiści jako elita inteligencji}

Michel Kennedy (1992: 70) pisze o dwóch zupełnie przeciwstawnych sposobach rozumienia i stosowania obu pojęć (intelektualistów i inteligencji): pierwsze polega na traktowaniu intelektualistów jako podzbioru inteligencji, wyróżniającego się od tej szerokiej kategorii predyspozycją do działań twórczych (creative powers) i zdolnościami do samodzielnej definicji; drugie rozumienie oparte jest na założeniu odwrotnym - to inteligencję można wyróżnić z większej kategorii intelektualistów. Identyfikowana jest ona poprzez inklinacje do teleologicznego rozumowania i charakterystycznej tożsamości kulturowej.

Już w tym miejscu należy więc zaznaczyć, że to pierwszy sposób rozumienia obu słów, traktujący intelektualistów jako podgrupę inteligencji, będzie dla tego artykułu obowiązujący. Obie kategorie społeczne stanowią pewien wzajemnie uzupełniający się układ - elity i jej publiczności. Wydaje się to być właściwą perspektywą dla polskich nauk społecznych. Już w 1960 r. J. Szczepański zwrócił uwagę, że to polscy intelektualiści (czyli tzw. inteligencja twórcza) nadali w XIX 
w. charakterystyczne cechy całej warstwie inteligenckiej, która pozostawała pod wpływem postaw, sposobów myślenia i stylu życia ich elity. I choć w krajach zachodnich należałoby raczej, podobnie jak czyni J. Schumpeter (1995), miano publiczności intelektualistów nadać burżuazji, a we współczesnych społeczeństwach klasie średniej (middle-class), to w Polsce właśnie inteligencja - ów zalążek klasy średniej - byłaby naturalnym odbiorcą intelektualistów.

Ponadto, jeśli mówimy o intelektualistach, mamy na myśli Sartre'a, Arona, Arendt, Foucaulta czy Miłosza i wiele innych, wybitnych umysłów; gdy zaś mówimy o inteligencji, myślimy o całej grupie, warstwie - pracownikach umysłowych, nauczycielach, lekarzach i adwokatach. Dlatego, że - jak pisze J. Żarnowski (1998) - intelektualistów traktuje się jako kategorię o wiele węższą, elitarną, wyodrębnioną funkcjonalnie, a nie profesjonalnie, jak to jest zazwyczaj w przypadku inteligencji. W tym sensie, mówiąc obrazowo, intelektualiści to po prostu lista nazwisk konkretnych osób, podczas gdy inteligencja będzie raczej zawierała się w liczbach, wykresach i statystycznych zestawieniach. Józef Chałasiński (1997: 65-66), niezależnie od krytyki jego koncepcji, do definicji inteligencji zaliczył tzw. stanowisko towarzyskie jako kryterium samoistne, jako element podstawowy społeczno-obyczajowego wzoru inteligenta. Dla niego inteligencja to „osobna warstwa społeczno-towarzyska”, podczas gdy intelektualista stanowi figurę niezależną. G.S. Morson (1993) ma więc rację, pisząc o większej skłonności inteligencji do konformizmu - postawy, polegającej na podejmowaniu decyzji politycznych, kulturowych czy ekonomicznych zgodnie z modą, narzuconą przez inteligenckie autorytety (czytaj: intelektualistów).

I choć XIX w. nieodłącznie związany jest w Polsce z inteligencją, która realizowała swój niepodległościowy czy też modernizacyjny projekt, to nie ma wątpliwości, że wśród tej warstwy od początku znajdowały się jednostki wybitne światłe, niepokorne umysły, niekwestionowane autorytety - inteligenci-społecznicy, przekazujący ludziom nie tylko wiedzę, ale też szczególną postawę moralną. Jednostki przodujące, najaktywniejsze, twórcze. Świadczą o tym, zarówno przytaczane już wcześniej myśli J. Szczepańskiego (1960, 1991), jak i Rodowody niepokornych B. Cywińskiego (2010). L. Krzywicki, E. Abramowski, S. Brzozowski - to przykłady osobistości zasługujących na miano pionierów XX-wiecznych polskich intelektualistów. I to oni oraz im podobni kształtowali polską inteligencję, rozpoczynając też tworzenie się polskiego środowiska intelektualnego.

We Francji - choć warstwa wykształconych pozbawiona była tej inteligenckiej misji - rola tych pierwszych intelektualistów była podobna - to oni kształtowali umysły stanu trzeciego. Twórcy kultury - po wielu romansach z władzą, do których dochodziło w tzw. salonach, gdzie spotykała się francuska elita 
- zdobywali sobie coraz większą autonomię, w coraz większym stopniu uniezależniając się od rządzących. Było to możliwe głównie dzięki ich publiczności, która nie tylko ich „kupowała”, ale też darzyła wielkim szacunkiem, budując ich społeczny autorytet. Jedno jest więc pewne, bez inteligencji (warstw wykształconych) nie byłoby intelektualistów (przynajmniej takich, jacy objawili się w XX w.). Dzięki nim intelektualista stał się kimś więcej niż tylko uczonym, artystą, filozofem czy literatem. Dzięki nim porzucił rolę nauczyciela, akademika i wykładowcy, rolę lokalnego mędrca, bezstronnego klerka, by stać się społecznym liderem, autorytetem, postacią utożsamianą z uniwersalnymi wartościami. $\mathrm{Z}$ drugiej strony, to dzięki intelektualistom, ludziom wychodzącym przed szereg, warstwy wykształcone zawdzięczają większą swobodę, większy zakres praw obywatelskich, a nawet poprawę swojej sytuacji materialnej. Intelektualiści stali się ich głosem na forum - ich pośrednikiem, dzięki któremu komunikują się zarówno z władzą, jak i innymi segmentami struktury społecznej.

„Analizując rolę intelektualistów [...], można powiedzieć, że ich nieustająca aktywność jest czynnikiem kształtującym odrębność inteligencji. Zresztą pod tym względem intelektualiści są do siebie podobni we wszystkich systemach społecznych. Można wysnuć tezę, że inteligencja będzie istnieć dopóty, dopóki istnieją intelektualiści" (Domański 2008: 13).

I choć teza, na bazie której stwierdzić należy, iż współczesny intelektualista wyrósł z warstwy wykształconej, nie do końca pasuje do koncepcji ,wykorzenienia” Mannheima (2008) i tylko połowicznie do tezy ,organiczności” A. Gramsciego (1961), to jednak prześledzenie rozwoju społecznej roli mędrca, człowieka wyższego intelektu, humanisty, klerka i w końcu intelektualisty pokazuje znakomicie, że główną publicznością, do której zwracał się intelektualista, była przede wszystkim inteligencja, warstwa ludzi wykształconych, wywodząca się zwłaszcza na Zachodzie - z burżuazyjno-mieszczańskich domów.

Tyle, że gdy na Zachodzie w drugiej połowie XX w. mogło się wydawać, że intelektualiści ulegają profesjonalizacji, przez co zaczęto ich postrzegać w kategoriach zawodowych (głównie więc jako professionals - specjalistów, doradców, ekspertów), tak w Polsce, dzięki specjalnym misjom (utrzymywanie egzystencji narodu pozbawionego własnej państwowości; zaangażowanie $\mathrm{w}$ budowanie socjalistycznego państwa; walka na rzecz demokratyzacji i liberalizacji systemu; walka z systemem socjalistycznym; budowanie demokratycznej rzeczywistości na zgliszczach socjalizmu), aż do końca XX w., intelektualiści nastawieni byli na twórczość kulturalną i zaangażowanie polityczne, na ciągłe nadawanie tonu i przewodniczenie rzeszy polskiej inteligencji. 
Kategorie intelektualistów na Zachodzie, pisarzy, poetów, uczonych i innych twórców wartości kulturalnych, żyjąc i pracując w „,normalnych” warunkach bytu politycznego swoich narodów, zbliżały się swoimi postawami społecznymi i funkcjami spełnianymi w społeczeństwie do inteligencji zawodowej. U nas ( $\mathrm{tj}$. w Polsce - przyp. TP) było odwrotnie (Szczepański 1960: 449-450).

Na plan pierwszy zostały więc wysunięte nie umiejętności zawodowe (jak to stało się na Zachodzie), ale twórczość kulturalna, powiązaną z misją - najpierw narodową, później socjalistyczną, a w końcu antysocjalistyczną, proliberalną i modernizacyjną (itd.). W polskich warunkach można zaś mówić o profesjonalizacji inteligencji, co nastąpiło po 1989 r. Ta przepełniona XIX-wiecznym etosem warstwa społeczna skupiła się po upadku ,żelaznej kurtyny" na swoich prywatnych sprawach i całkiem partykularnych celach. To intelektualiści wciąż mieli jakąś misję do spełnienia (np. nie dopuścić do odrodzenia polskiego nacjonalizmu albo przeprowadzić rewolucję moralną, budując IV RP czy też nie dopuścić do jej zbudowania, broniąc III RP - misji tego typu można wymienić wiele), uzurpując sobie prawo do wskazywania polskiemu społeczeństwu, jako kierunkowskaz, w którą stronę należy zmierzać.

A. Gramsci (1961), mówiąc o tym, że każda warstwa tworzy swoich intelektualistów, może mieć rację, ale dopiero od pewnego momentu w dziejach. Powszechność edukacji i powstanie masowych ruchów politycznych sprawiły, że obok ,,intelektualisty tradycyjnego”, pojawił się także ,intelektualista organiczny”. Podobnie, nie należy dyskutować z poglądem R. Mertona (2002: 270) mówiącym, że publicznością intelektualisty jest całe społeczeństwo - tyle że stwierdzenie to nabiera słuszności dopiero w rzeczywistości demokratycznej, obecnej w mass media. Nie ulega więc wątpliwości, że to zaistnienie systemu demokratycznego pozwoliło intelektualistom realizować się (publicznie) w pełni. Jak zaznaczał H. Domański (2008: 13), dopiero upadek systemu komunistycznego w Polsce pozwolił intelektualistom zaistnieć w o wiele większym stopniu niż wcześniej.

\section{Próba polowania}

Spory na temat definicji intelektualistów toczą się od przeszło 100 lat - przede wszystkim od czasów afery Dreyfusa. Wciąż jednak nie dopracowano się jednej ścisłej definicji tego społecznego zjawiska. Ma to, poza wieloma oczywistymi dla badacza wadami, także swoje pozytywne strony - umożliwia zastosowanie terminu do różnych warunków społecznych i okoliczności historycznych, do wielu typów społeczeństw i różnych szerokości geograficznych. 
Zdaniem S. Colliniego (2006: 46), istnieją jednak co najmniej trzy znaczenia „,intelektualistów”, które ciągle są ze sobą mylone. Po pierwsze, w sensie socjologicznym, odnoszące się do całego szeregu kategorii społeczno-zawodowych, rozciągających się w dużych społeczeństwach rozwiniętych, których liczby członków idą w miliony. Po drugie, w sensie przedmiotowym, gdy uwaga skupia się na indywidualnym poziomie zainteresowania lub stosunku do idei, niezależnie od ich zawodu lub roli społecznej. I po trzecie - zdaniem naukowca z Cambridge obecnie dominujące, które możemy nazwać kulturowym, w którym termin określa te postacie, które bazują na uznanym autorytecie w działalności twórczej, naukowej lub innej, przyznając sobie możliwość adresowania do szerszej publiczności opinii w sprawach natury ogólnej.

To ostatnie ujęcie wydaje się najbardziej przystawać do samych początków tego zjawiska, czyli afery Dreyfusa i grupowych wystąpień twórców kultury na forum publicznym. Francuski model zdominował sposób postrzegania intelektualistów - polityczna interwencja stała się konstytutywnym elementem definicji tejże kategorii. Tak powstał wzorzec adekwatny także do lokalnych porównań w innych krajach. Zdobyty kapitał kulturowy ma umożliwiać uczonym, pisarzom, dziennikarzom i artystom połączenie dużej rozpoznawalności i popularności oraz nabytych specjalnych dyspozycji do formułowania swych myśli publicznie i kierowania ich do niewyspecjalizowanych odbiorców w sprawach powszechnego zainteresowania. I choć S. Collini (2006: 49-51) odrzuca tezę, że działalność polityczna jako taka jest zasadniczym obowiązkiem intelektualisty, uważając, że konstytutywną częścią znaczenia tego terminu jest zaś jego publiczna rola, to wydaje się, że ową ,polityczność” należy raczej rozumieć w duchu republikańskim (polityka to my - wszyscy obywatele). Społeczne zaangażowanie intelektualisty to nie tylko twórcza aktywność umysłowa, ale podjęcie odpowiedzialności i zajęcie określonego stanowiska w sporze politycznym. Nie musi to więc od razu oznaczać zaangażowania w politykę tej czy innej partii, w zamierzeniu jednak „ma służyć bitwie o ludzkie serca i umysły” (Furedi 2004: 41).

Istnieje oczywiście koncepcja traktująca intelektualistów jako wszystkich twórców kultury, inteligencję twórczą czy po prostu kreatorów idei, co odpowiadałoby definicji Maxa Webera (1946: 176, tłum. za Szacki 1991: 386), traktującej intelektualistów jako grupę ludzi, którzy ,z racji swej odrębności mają szczególny dostęp do pewnych osiągnięć uważanych za „,wartości kultury” i którzy na tej podstawie roszczą sobie prawo do przewodzenia zbiorowości kulturowej”. To oni mieliby odpowiadać za „odczarowanie świata” - tj. za kompleksową i sensowną interpretację świata (racjonalizację). W tym znaczeniu, intelektualiści mieliby się parać przede wszystkim samą kulturą, symbolami i myślą jako taką, a nie administracją, produkcją czy w końcu - polityką (te byłyby tylko pochodną ich działań kulturowych). Ich działalność niekoniecznie musiałaby stronić od formułowania 
sądów, mających zastosowanie praktyczne, ale główną radość powinni oni czerpać z uprawiania sztuki, nauki i rozważań filozoficznych. $\mathrm{Z}$ tej perspektywy, intelektualistą jest się więc niezależnie od wejścia w pole polityczne - jest się nim po prostu dzięki wykonywaniu „zwykłych” czynności przynależących do pisarza, artysty, naukowca. To rozumienie odpowiadałoby wskazanemu przez J. Szackiego (1991) wyobrażeniu ,intelektualisty kulturowego”, którego fenomen jest właściwie ponadhistoryczny. Tę kategorię opisywano więc zazwyczaj w idealistyczny sposób - jako ludzi obcujących z innym światem, pośredników boskich idei, przedstawicieli Rozumu i powszechnej moralności. Praktyka jednak pokazała, że nawet optowanie za uniwersalnymi ideami wiązało się ze sprzyjaniem konkretnej stronie sporu politycznego (jak chociażby w sprawie Dreyfusa).

R. Eyerman (2011) uważa, że intelektualista to specyficzna rola społeczna, obejmująca formułowanie idei przekazywanych do szerokiego grona odbiorców poprzez różne media i fora w celu wywarcia wpływu na opinię publiczną. Są więc nimi artyści, dziennikarze i pisarze - naukowców i innych pracowników umysłowych, dopóki wykonują normalnie swoje obowiązki, należy z tej grupy wykluczyć. Co oznacza, że ci ostatni intelektualistami mogą być jedynie wtedy, kiedy zaczną wypowiadać się w mediach masowych, pisać artykuły i dzielić się swoimi poglądami na szerokim forum publicznym. Społeczne zaangażowanie intelektualisty to właśnie publiczna manifestacja określonej moralności, czy - jak twierdziliby idealiści - moralności uniwersalnej, tyle tylko, że definiowalnej z różnych społecznych perspektyw. Skład uniwersalnych wartości dla osób o lewicowych bądź prawicowych poglądach wszak nie jest taki sam.

Słusznie zauważa J. Szacki (1991: 384), że termin ,intelektualista” ma przede wszystkim jednak sens polityczny: wskazuje na osobę, która nie tylko zajmuje określone miejsce w strukturze społecznej, nie tylko posiada konkretne wykształcenie i trudni się wykonywaniem takiego, a nie innego zawodu, ale przede wszystkim zachowuje się w określony sposób. Zatem bycie intelektualistą wiąże się z występowaniem w podwójnej roli społecznej - z jednej strony roli specjalisty $w$ takiej lub innej dziedzinie pracy intelektualnej, a $z$ drugiej, roli człowieka, który z jakichś powodów czuje się powołany do zaangażowania się w sprawy społeczne, do aktywnego uczestnictwa, a nawet przewodzenia określonej wspólnocie ponadzawodowej.

Jeśli intelektualistami nazwiemy „nie ogół ludzi wykonujących pracę intelektualną [...], lecz tylko pewną ich część [...], która zdecydowała się wyjść ze swoich „laboratoriów czy bibliotek” na polityczny rynek, na forum życia publicznego" (Szacki 1991: 384), to z tego wynikałby wniosek, że intelektualistą jest się jedynie dzięki zaangażowaniu - ci więc, co pozostają w wieży z kości 
słoniowej, na takie miano „nie zasługują”. Ten dość paradoksalny charakter ludzi wyższego intelektu znakomicie oddaje P. Bourdieu (2007: 508), przekonując, że o intelektualiście nie da się pomyśleć tak długo, ,,jak ujmuje się go w wymuszonej alternatywie autonomii i zaangażowania, kultury czystej i polityki. A to dlatego, że [...] intelektualista narodził się w i dzięki przekroczeniu tej opozycji”.

Intelektualista, jak pisał L. Kołakowski (2012), za pomocą słowa pragnie zaproponować własną interpretację świata i udostępnić lub narzucić tę nową percepcję odbioru rzeczywistości innym, chcąc prawdę nie tylko przekazywać, ale i ją tworzyć, kreując przez to nowy świat. I to w tym kontekście eyermanowskie „formułowanie pomysłów zgłaszanych do szerokiej publiczności” (Eyerman 2011) nabiera nowego sensu - jako tworzenie intelektualnych projektów, mających wpłynąć na bieg zdarzeń, i szukania poparcia dla nich. Projektów, które zbudowane są na podłożu ideowym i odnoszą się do określonych systemów wartości - w tym przypadku samo ich przedłożenie jest wyrazem zaangażowania na rzecz zmiany istniejącej rzeczywistości (lub obrony przed zmianą).

Można by więc zaproponować następującą definicję intelektualistów, traktując ich jako wybitnych przedstawicieli szeroko rozumianych twórców kultury, którzy wykraczając poza swoje kompetencje zawodowe, angażują się w mniej lub bardziej wyrazisty sposób w życie społeczno-polityczne i biorą udział w debacie publicznej, wyrażając opinie lub zajmując konkretne stanowisko w sprawie, wpływając tym samym na swoją publiczność. Taka operacjonalizacja pojęcia może prowadzić do wniosku, że najlepszym sposobem, aby precyzyjnie wyjaśnić kategorię intelektualistów jest analiza obecności twórców kultury w życiu publicznym, próbująca wychwycić przede wszystkim podjęte przez nich decyzje - wejścia, zaangażowania się. W końcu już samo zaobserwowanie podjętych działań twórców kultury na forum publicznym umożliwia wskazanie, jaka decyzja została przez nich podjęta. Skoro współcześnie jednak nie każda obecność twórców kultury w mediach ma charakter polityczny, a najczęściej ekspercki lub rozrywkowy (jako celebryta), to tym szczególnym wyrazem woli, i owocem ich działania, jest złożenie własnego podpisu pod listem otwartym (manifestem).

Intelektualista jako odrębna figura społeczna rodzi się wówczas, gdy interweniuje on w polu politycznym w imię specyficznych wartości pola produkcji kulturowej (pola twórców kultury) - wówczas możemy mówić o narodzinach pola intelektualnego i jego autonomii (praw rządzących tym polem) (Bourdieu 2007). We Francji tym momentem była afera Dreyfusa i to na jej przykładzie Bourdieu buduje swoją koncepcję intelektualisty - momentu ,powstania” i dalszego funkcjonowania w życiu publicznym. W ten sposób wskazano na narodziny intelektualistów francuskich (i intelektualistów w ogóle) i wydaje się, że na zasadzie analogii należy poszukać genezy pola intelektualnego także w kraju nad Wisłą - nie będzie to bowiem moment paralelny do francuskiego fin de siècle. 
W Polsce jednoznaczne ukazanie tych narodzin będzie wyjątkowo trudne ze względu na polską, niełatwą historię, niestabilną sytuację polskiego państwa (którego zresztą, wówczas gdy narodził się intelektualista francuski, w ogóle nie było) oraz niedemokratyczną rzeczywistość. Wymóg swobód demokratycznych związany jest z postawą krytyczną intelektualisty, która to nie jest możliwa w pełni, gdy wolność myślenia i formułowania wypowiedzi ograniczona jest jak w średniowieczu - przez królewskie, książęce czy zakonne cugle, a współcześnie, gdy nie ma demokracji, autorytarne czy totalitarne bariery.

Za swoisty, rozumiany dość symbolicznie, początek polskiego pola intelektualnego i narodziny współczesnego nam typu intelektualisty uznać należy zgodnie z francuskim przykładem afery Dreyfusa - protest twórców kultury, którzy niejako wychodząc ze swej roli, na mocy wolnej decyzji (choć podejmowanej nie do końca w wolnej rzeczywistości) zdecydowali się zaangażować i wejść tym samym w sferę polityczną, pisząc list, nazywany później od liczby sygnatariuszy „Listem 34”. Było to pismo protestacyjne, skierowane 14 III 1964 r. na ręce premiera J. Cyrankiewicza, domagające się złagodzenia cenzury i większych przydziałów papieru. Był to moment uruchomienia i pobudzenia polskiego środowiska intelektualnego, który pokazał możliwą drogę sprzeciwu i krytycznego reagowania na poszczególne decyzje polityczne. Konsekwencją, przynajmniej pośrednią, tego zdarzenia był Marzec 1968 roku oraz kolejne tego typu listy intelektualistów (m.in. List 15, List 44, List 59, List 14, ale także List otwarty do partii). Wskazując na „List 34” z 1964 r., można jednocześnie postawić hipotezę, że wydarzenie to było pierwszym w pełni można świadomym aktem walki intelektualistów o autonomię własnego środowiska.

Jest więcej niż pewne, że oparcie analizy na listach otwartych intelektualistów nie w każdych warunkach historycznych i terytorialnych znajdzie swoje uzasadnienie. W wielu krajach brakuje takiej tradycji - odporny na intelektualistów świat anglosaski nie znalazłby zapewne wielu tego typu manifestów, na bazie których można byłoby wyłaniać poszczególnych intelektualistów. Polskie środowisko intelektualne wydaje się jednak bliższe francuskiemu i to temu sprzed niemal 100 lat. Przecież Manifeste des intellectuels wiązał się zarówno z narodzinami nowej kategorii społecznej, jak i - choć w sposób bardziej pośredni z początkami kształtowania się francuskiej demokracji.

Ideologiczne, a zwłaszcza totalitarne, zaangażowanie mocno nadszarpnęło społeczny autorytet intelektualistów w połowie XX w. Na Zachodzie, począwszy od lat 60., intelektualny świat zaczął ulegać profesjonalizacji. Intelektualiści zaczęli zamieniać się w ekspertów, doradców i komentatorów. Po wschodniej zaś stronie żelaznej kurtyny, dopiero rozpoczynał się powolny proces starań twórców 
kultury o autonomię tworzenia, którą stopniowo budowano głównie poprzez akcje polityczne, ścierając się z partyjnymi decydentami. Intelektualiści znowu zaczęli w socjalistycznym systemie zajmować „miejsce szczególne”, choć rozumiane na opak - jako jednostki rewizjonistyczne, a w końcu nawet antysystemowe. Ich udział w upadku systemu komunistycznego był na tyle duży, że niektórzy polską Jesień Narodów z 1989 r. byli w stanie nazwać ,rewolucją intelektualistów" (Ash 1990).

\section{Bibliografia}

Amszejewicz M. (1859), Dykcjonarz, Drukarnia Alexandra Gins, Warszawa.

Ash T.G. (1990), Wiosna obywateli. Rewolucja 1989 widziana w Warszawie, Budapeszcie, Berlinie

i Pradze, Polonia, Londyn.

Bacon F. (1915), The Advancement of Learning, Dent, London.

Bauman Z. (1998), Prawodawcy i ttumacze, IFiS PAN, Warszawa.

Benda J. (1900), Dialogues à Byzance, Editions de la Revue Blanche, Paris.

Benda J. (1928), The Treason of Intellectuals, William Morrow Ed., New York.

Bourdieu P. (2007), Reguły sztuki, Universitas, Kraków.

Chałasiński J. (1997), Przeszłość i przysztość inteligencji polskiej, Świat Książki, Warszawa.

Collini S. (2006), Absent Minds. Intellectuals in Britain, Oxford University Press, Oxford.

Cywiński B. (2010), Rodowody niepokornych, Wydawnictwo Naukowe PWN, Warszawa.

Domański H. (2008), Wstęp, [w:] H. Domański (red.), Inteligencja w Polsce. Specjaliści, twórcy, klerkowie, klasa średnia?, IFiS PAN, Warszawa.

Drake D. (2005), French Intellectuals and Politics from the Dreyfus Affair to the Occupation, Palgrave Macmillan, Basingstoke.

Eyerman R. (2011), Intellectuals and cultural trauma, „European Journal of Social Theory”, vol. $14(4)$.

Fik M. (1997), Autorytecie wróć? Szkice o postawach polskich intelektualistów po październiku 1956, Errata, Warszawa.

Fuller S. (2005), The Intellectual, Icon Books, Cambridge.

Furedi F. (2004), Gdzie się podziali wszyscy intelektualiści?, PIW, Warszawa.

Gramsci A. (1961), Intelektualiści i organizowanie kultury, [w:] A. Gramsci, Pisma wybrane, t. I, Książka i Wiedza, Warszawa.

Kennedy M. (1992), The Intelligentsia in the Constitution of Civil Societies and Post-Communist Regimes in Hungary and Poland, ,Theory and Society”, vol. 21, no. 1. 
Kołakowski L. (2012), Intelektualiści, [w:] L. Kołakowski, Czy diabet może być zbawiony i 27 innych kazań, Znak, Kraków.

Madajczyk Cz. (1999), Klerk czy intelektualista zaangażowany? Świat polityki wobec twórców kultury i naukowców europejskich w pierwszej połowie XX wieku, Wydawnictwo Poznańskie, Poznań.

Merton R. (2002), Teoria socjologiczna i struktura społeczna, Wydawnictwo Naukowe PWN, Warszawa.

Micińska M. (2000), Czy istnieja angielscy intelektualiści? Problematyka elit intelektualnych w historiografii brytyjskiej, „Kultura i Społeczeństwo”, nr 2.

Morson G.S. (1993), What is the intelligentsia? Once more, an old russian question, „Academic Question", Summer.

Ory P., Sirinelli J. (2002), Les Intellectuals en France, de l'Affaire Deeyfus à nos jours, Armand Colin, Paris.

Schumpeter J. (1995), Kapitalizm, socjalizm, demokracja, Wydawnictwo Naukowe PWN, Warszawa.

Szacki J. (1991), Intelektualiści pomiędzy kulturą a polityka, [w:] J. Szacki, Dylematy historiografii idei oraz inne szkice i studia, Wydawnictwo Naukowe PWN, Warszawa.

Szczepański J. (1960), Zakończenie, [w:] J. Szczepański (red.), Wyksztatcenie a pozycja społeczna inteligencji, cz. 2, PWN, Łódź.

Szczepański J. (1991), Intelektualiści, [w:] A. Kłoskowska (red.), Encyklopedia kultury polskiej XX wieku. Pojęcia i problemy wiedzy o kulturze, Wiedza o kulturze, Wrocław.

Żarnowski J. (1998), Intelektualiści, [w:] Encyklopedia socjologii, t. 1, Oficyna Naukowa, Warszawa. 